\title{
Indexes of power and aerobic capacity obtained in cycle ergometry and treadmill running: comparisons between sedentary, runners, cyclists and triathletes*
}

\author{
Fabrizio Caputo ${ }^{1}$, Sérgio Garcia Stella ${ }^{2}$, Marco Túlio de Mello $^{2}$ and Benedito Sérgio Denadai ${ }^{1}$
}

\begin{abstract}
The objectives of this study were: a) to determine, in a cross-sectional manner, the effect of aerobic training on the peak oxygen uptake $\left(\dot{\mathrm{V}}_{2 \text { peak }}\right)$, the intensity at $\dot{\mathrm{V}} \mathrm{O}_{\text {2peak }}$ $\left(\mathrm{IVO}_{2 \text { peak }}\right)$ and the anaerobic threshold (AnT) during running and cycling; and b) to verify if the transference of the training effects are dependent on the analized type of exercise or physiological index. Eleven untrained males (UN), nine endurance cyclists (EC), seven endurance runners (ER), and nine triathletes (TR) were submitted, on separate days, to incremental tests until voluntary exhaustion on a mechanical braked cycle ergometer and on a treadmill. The values of $\dot{V O}_{\text {2pak }}\left(\mathrm{ml} \mathrm{kg}^{-1} \cdot \mathrm{min}^{-1}\right)$ obtained in running and cycle ergometer $(\mathrm{ER}=68.8 \pm 6.3$ and $62.0 \pm 5.0 ; \mathrm{EC}=60.5 \pm 8.0$ and $67.6 \pm 7.6 ; \mathrm{TR}=64.5 \pm 4.8$ and $61.0 \pm 4.1 ; \mathrm{UN}=43.5 \pm$ 7.0 and $36.7 \pm 5.6$; respectively) were higher in the group that presented specific training in the modality. The UN group presented the lower values of $\dot{\mathrm{V}} \mathrm{O}_{2 \text { peak }}$, regardless of the type of exercise. This same behavior was observed for the AnT $\left(\mathrm{ml}^{\mathrm{kg}}{ }^{-1} \cdot \mathrm{min}^{-1}\right)$ determined in running and cycle ergometer $(\mathrm{ER}=56.8 \pm 6.9$ and $44.8 \pm 5.7 ; \mathrm{EC}=51.2 \pm 5.2$ and $57.6 \pm 7.1 ; \mathrm{TR}=56.5 \pm 5.1$ and $49.0 \pm 4.8 ; \mathrm{UN}=33.2 \pm$ 4.2 and $22.6 \pm 3.7$; respectively). It can be concluded that the transference of the training effects seems to be only partial, independently of the index $\left(\dot{\mathrm{V}}_{2 \text { peak }}, \mathrm{IV}_{2 \text { peak }}\right.$ or $\left.\mathrm{AnT}\right)$
\end{abstract}

\footnotetext{
* Financial support: CNPq and Fapesp.

1. Laboratório de Avaliação da Performance Humana - Unesp, Rio ClaroSP.

2. Centro de Estudos em Psicobiologia e Exercício - EPM-Unifesp-SP.

Received in 18/2/03

Approved in 14/7/03
}

Correspondence to:

B.S. Denadai

Laboratório de Avaliação da Performance Humana, IB - Unesp

Av. 24A, 1.515 - Bela Vista

13506-900 - Rio Claro, SP - Brasil

E-mail: bdenadai@rc.unesp.br or exercise type (running or cycling). In relation to the indices, the specificity of training seems to be less present in the $\dot{\mathrm{V}} \mathrm{O}_{2 \text { peak }}$ than in the $\mathrm{IVO}_{2 \text { peak }}$ and the AnT.

Key words: Specificity. Maximal oxygen uptake. Anaerobic threshold. Running. Cycling.

\section{INTRODUCTION}

The effects of training on the body depend on the interaction of at least three factors: initial fitness level; applied overload (intensity, duration, and weekly frequency); and type of exercise (movement specificity).

The possible transference of the training effects from one type of exercise to another has been broadly investigated. This model of study is rather interesting, as it allows one to assess the physiologic mechanisms accountable for and/or limit body adjustments to training. Moreover, such data also interest the professionals in charge of assessment and training multiple-sports athletes (biathlon and triathlon), or injured athletes who need, for a period of time, to replace the type of movement they perform in their training.

Most of the studies that investigated the transference of the effects from aerobic training between different body segments (arm-leg or leg-arm) found that adjustments were limited to the trained segment ${ }^{1-3}$.

Studies that assessed such transference among the same body segments, but using different exercises (cycling-running or running-cycling), have collected data one may consider conflicting. In these studies, it has been noted that cycling-running and running-cycling may be similar $^{4}$, higher from cycling to running 5 or from running to cycling ${ }^{6}$. Such contraposition may be explained, in part, by lack of control and/or difference in the initial fitness status of the subjects in the previously mentioned studies. So, it has been suggested that transferences would be lower and lower, with the enhancement of the initial fitness status and, conversely, with sensitivity decrease of the training effects. Howev- 
er, very recent data collected from triathletes ${ }^{3}$ have shown that effects from cycling were transferred to running performance (longer distance covered in 30 minutes), which shows that, even in athletes, transference (at least for the performance) from cycling effects to running could exist.

Another less investigated aspect is that the magnitude of the training effects transference between running and cycling could depend on the physiologic indices used to determine training effects. As the peak oxygen uptake $\left(\dot{\mathrm{V}}_{2 \text { peak }}\right)$ found in a maximum exertion test has been considered the golden standard to determine functional fitness of the cardiorespiratory system during physical activity ${ }^{7}$, a number of studies used it alone to assess possible transferences from training effects. However, this may not be the most suitable index, as a number of studies found, in moderately or highly trained subjects, that there may little or even no change in $\mathrm{V}_{2 \text { paak }}$, even though some adjustments and improvement of aerobic performance may occur with training $^{8}$. To confirm this, studies have found that short- (2-5 $\mathrm{min}$ ), medium- (5-30 $\mathrm{min})$, or long-term (> $30 \mathrm{~min}$ ) performance does not depend on $\mathrm{VO}_{2}$ peak $^{9,10}$ alone. This happens because, in trained subjects, $\dot{\mathrm{V}}_{2 \text { peak }}$ seems to be limited by the central oxygen supply (maximum cardiac output) ${ }^{11}$, which, from a specific fitness level upward, does not change due to training. For the exercise intensity corresponding to $\dot{\mathrm{V}} \mathrm{O}_{2 \text { peak }}\left(\mathrm{IV}^{\mathrm{V}} \mathrm{O}_{2 \text { paak }}\right)$, which is the best index to reflect the association between maximum aerobic power and economy of movement ${ }^{12}$, the aspects previously discussed do not seem to occur. $\mathrm{IV}_{2 \text { peak }}$ has shown to be a good aerobic performance predictor, and it is also sensitive to the effects of training in athletes, even when $\dot{\mathrm{V}} \mathrm{O}_{2 \text { peak }}$ does not change, as there may be an improvement in the economy of movement ${ }^{13}$. The same seems to take place with lactate response to incremental exercises (known in general terms as anaerobic threshold - AnT), which, as depending more of peripheral adaptations (muscular oxidative capability), is highly sensitive to training effects, and also presents high correlation with aerobic performance in medium- and long-duration events ${ }^{14}$. Notwithstanding, few studies have used AnT and, as far as we know, no study so far has investigated $\mathrm{IVO}_{2 \text { peak }}$ to determine training effects transferences among different types of exercise.

The studies that make a longitudinal assessment of training effects may be considered, at first, the best investigative models. In these models, possible influences of the genetic load on the investigated indices are potentially best controlled. On the other hand, almost all these longitudinal studies covered somewhat small periods of time (4 to 24 weeks), which makes the collection of information on adjustments that may occur over the longer term with training (1 to 2 years) more difficult to obtain.
Thus, the purposes of this investigation were: a) to determine, in a cross-sectional way, training effects on $\mathrm{V}_{2 \text { peak }}$, $\mathrm{IVO}_{2 \text { peak }}$ and AnT during running and cycling; and b) to check if the transference of training effects depends on the type of exercise or the physiological index investigated.

\section{MATERIAL AND METHODS}

\section{Subjects}

Seven runners (ER: $25.8 \pm 6.0$ years, $60.4 \pm 4.1 \mathrm{~kg}, 172.1$ $\pm 6.9 \mathrm{~cm}$ ), 9 cyclists (EC: $22.6 \pm 2.1$ years, $62.8 \pm 5.4 \mathrm{~kg}$, $173.8 \pm 5.9 \mathrm{~cm}$ ), and 9 triathletes (TR: $21.4 \pm 4.1$ years; $66,2 \pm 7,0 \mathrm{~kg} ; 174.2 \pm 8.4 \mathrm{~cm}$ ) well trained in endurance tests, and 11 untrained individuals (UN: $26.8 \pm 4.1$ years, $74.9 \pm 14.3 \mathrm{~kg}, 175.1 \pm 5.1 \mathrm{~cm}$ ), all males, took part in the study. The athletes had, at least, two years practice in their specific modality. Each volunteer was informed on the investigation procedures and their implications, and signed an informed consent form to take part in the study. The protocol was approved by the Research Ethics Committee of the Biosciences Institute - Unesp - Rio Claro.

\section{Experimental procedures}

Each volunteer took part in two experimental sessions, which were randomly carried out, with intervals of 5 to 7 days between the sessions. The subjects were advised to come to the tests rested, fed, and hydrated, and not having done heavy exertion over the past 48 hours. Each volunteer attended both sessions at the same place and time of day ( \pm 2 hours).

The running tests were performed on a treadmill (Inbramed Millenium Super ATL) at an inclination of $1 \%$. Cycling tests were performed on a braked cycle ergometer, with constant rotation of $70 \mathrm{rpm}$ throughout the test. Respiratory variables were measured by a gas analyzer (Cosmed K4, Rome, Italy), collecting data breath-by-breath and calculating an average at every 15 seconds. Blood samples were analyzed by a lactate electrochemical analyzer (YSL 2300 STAT), and heart rate was monitored through a frequency-meter (Polar X - Trainer plus).

\section{Determining $\dot{\mathrm{V}} \mathrm{O}_{2 \text { peak }}, \mathrm{IV}_{\mathrm{V} \mathrm{O}_{2 \text { peak }}}$ and AnT}

The initial speed of the incremental test performed on the treadmill was $14 \mathrm{~km} \cdot \mathrm{h}^{-1}$ for runners and triathletes, and $9 \mathrm{~km} \cdot \mathrm{h}^{-1}$ for the other subjects, with $1 \mathrm{~km} \cdot \mathrm{h}^{-1}$ increments at every 3 minutes until voluntary exhaustion. At the end of each stage, there was a 30-second pause, when heart rate (HR) was measured and $25 \mathrm{ml}$ of blood from the ear lobule were collected.

For the progressive and continuous cycle ergometer test, the initial load was of $105 \mathrm{~W}$ for cyclists and triathletes, and $70 \mathrm{~W}$ for the other subjects, with increments of $35 \mathrm{~W}$ 
at every 3 min until voluntary exhaustion. At the end of each stage, HR was measured and $25 \mathrm{ml}$ of blood from the ear lobule was collected, with no pause.

The highest $\mathrm{VO}_{2}$ measured within 15 seconds was considered $\dot{\mathrm{V}} \mathrm{O}_{2 \text { peak }}$. $\mathrm{IVO}_{2 \text { peak }}$ was the lowest speed or power $\dot{\mathrm{V}} \mathrm{O}_{2 \text { paak }}$ measurement. If the intensity of the measured $\dot{\mathrm{VO}}_{2 \text { peak }}$ was not sustained for at least 1 minute, the intensity of the previous stage was considered $\mathrm{IVO}_{2 \text { peak }}{ }^{15}$. AnT was calculated through linear interpolation, assuming a fixed lactate concentration of $3.5 \mathrm{mM}^{16}$.

\section{Statistical analysis}

All data are expressed as means \pm DP. Values for $\dot{\mathrm{V}}_{2 \text { peak }}$, maximum heart rate (HRmax), peak lactate, AnT in absolute figures $\left(\dot{\mathrm{VO}}_{2 \mathrm{AnT}}\right)$ and as a proportion of $\dot{\mathrm{V}} \mathrm{O}_{2 \text { peak }}$ $\left(\right.$ AnT\% $\dot{\mathrm{VO}}_{2 \text { peak }}$ ), AnT-related heart rate (HRAnT), and HRAnT in relation to HRmax (AnT\%HRmax) were assessed with the use of an ANOVA two-way (group vs. modality), complemented by Scheffé's test. IV $\mathrm{I}_{2 \text { peak }}$ comparison was done with the use of an ANOVA one-way, complemented by Scheffé's test. In all tests a significance level of $p<0.05$ was adopted.

\section{RESULTS}

$\dot{\mathrm{V}} \mathrm{O}_{2 \text { peak }}$ values are presented in figure 1 and in table 1 . $\dot{\mathrm{V}} \mathrm{O}_{2 \text { peak }}$ was significantly higher in running than cycling for ER and UN groups. For the TR group there was no difference between the exercises, and for the EC group, $\dot{\mathrm{V}} \mathrm{O}_{2 \text { peak }}$ was higher in cycling. UN group presented a $\dot{\mathrm{VO}}_{2 \text { peak }}$ lower than the other groups, for both types of exercise. Comparison of ER and EC groups showed that $\mathrm{V}_{\text {2paak }}$ was higher for those where athletes had specific training. Group TR had a $\dot{\mathrm{VO}}_{2 \text { paak }}$ lower than group EC for cycling, and it was statistically similar for running. As for ER group, $\mathrm{VO}_{2 \text { peak }}$ values of the TR groups were not different for both types of exercise.

Figures 2 and 3 show $\mathrm{IV}_{2 \text { peak }}$ from running and cycling, respectively. $\mathrm{IVO}_{2 \text { peak }}$ of the UM group was lower than the other groups, for both types of exercises. For running, ER group showed $\mathrm{IVO}_{2 \text { peak }}$ higher than the one from CL group, whereas for cycling, EC group had $\mathrm{IV}_{2 \text { paak }}$ higher than the one from the ER group. IV ${ }_{2 \text { peak }}$ of the TR group was not different from the one of the EC group, and significantly

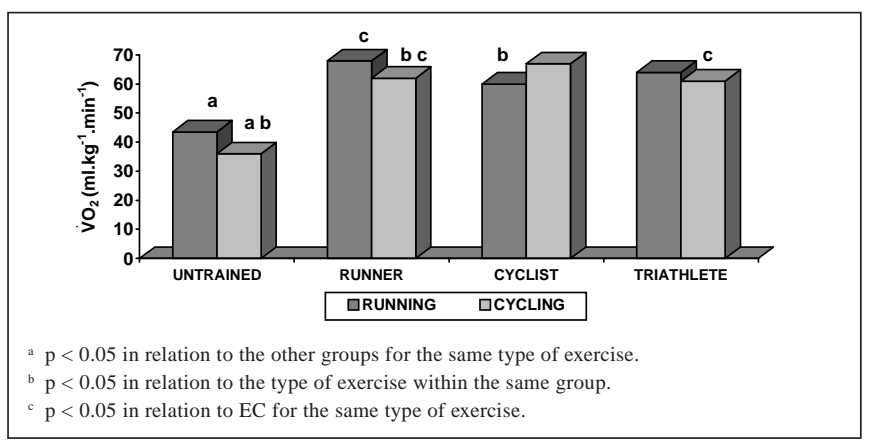

Fig. 1 - Mean peak oxygen uptake values $\left(\dot{V} O_{2 \text { peak }}\right)$ from treadmill and cycle ergometer for untrained $(U N)$, runners $(E R)$, cyclists $(E C)$ and triathletes $(T R)$ groups

TABLE 1

Mean values \pm SD of peak oxygen uptake $\left(\dot{V} \mathrm{O}_{2 \text { peak }}\right)$, of the intensity corresponding to $\dot{\mathrm{V}} \mathrm{O}_{2 \text { peak }}$

$\left({ }^{\prime} \mathrm{VO}_{2 \text { peak }}\right)$, of maximum heart rate (HRmax) and of peak lactate (LACpeak) from cycle ergometer and treadmill for untrained (UN), runners (ER), cyclists (EC) and triathletes (TR) groups

\begin{tabular}{|c|c|c|c|c|c|}
\hline \multirow[t]{2}{*}{ Variables } & \multirow[t]{2}{*}{ Ergometer } & \multicolumn{4}{|c|}{ Group } \\
\hline & & $\begin{array}{c}\text { UN } \\
(n=11)\end{array}$ & $\begin{array}{c}\text { ER } \\
(n=7)\end{array}$ & $\begin{array}{c}E C \\
(n=9)\end{array}$ & $\begin{array}{c}\text { TR } \\
(n=9)\end{array}$ \\
\hline$\dot{\mathrm{V}} \mathrm{O}_{2 \text { peak }}\left(\mathrm{ml} \cdot \mathrm{kg}^{-1} \cdot \mathrm{min}^{-1}\right)$ & $\begin{array}{l}\text { Treadmill } \\
\text { Cycle }\end{array}$ & $\begin{array}{l}43.5 \pm 7.0^{\mathrm{a}} \\
36.7 \pm 5.6^{\mathrm{ab}}\end{array}$ & $\begin{array}{l}68.8 \pm 6.3^{c} \\
62.0 \pm 5.0^{b c}\end{array}$ & $\begin{array}{l}60.5 \pm 8.0^{b} \\
67.6 \pm 7.6\end{array}$ & $\begin{array}{l}64.5 \pm 4.8 \\
61.0 \pm 4.1^{c}\end{array}$ \\
\hline $\mathrm{IVO}_{2 \text { peak }}$ & $\begin{array}{l}\text { Treadmill* } \\
\text { Cycle** }\end{array}$ & $\begin{array}{r}12.8 \pm 1.0^{\mathrm{a}} \\
200.3 \pm 36.2^{\mathrm{a}}\end{array}$ & $\begin{array}{c}19.7 \pm 1.7 \\
267.4 \pm 35.9 \mathrm{e}\end{array}$ & $\begin{array}{c}16.4 \pm 1.2^{d} \\
332.2 \pm 41.3\end{array}$ & $\begin{array}{r}19.2 \pm 1.2 \\
328.5 \pm 47.1\end{array}$ \\
\hline HRmax (bpm) & $\begin{array}{l}\text { Treadmill } \\
\text { Cycle }\end{array}$ & $\begin{array}{l}199.1 \pm 7.1 \\
186.2 \pm 6.8^{b}\end{array}$ & $\begin{array}{l}195.4 \pm 5.7 \\
181.0 \pm 14.3^{b}\end{array}$ & $\begin{array}{l}194.8 \pm 10.6 \\
191.0 \pm 8.4^{d}\end{array}$ & $\begin{array}{l}193.0 \pm 11.2 \\
182.4 \pm 5.7 b\end{array}$ \\
\hline [LAC] peak (mM) & $\begin{array}{l}\text { Treadmill } \\
\text { Cycle }\end{array}$ & $\begin{array}{r}9.1 \pm 1.9 \\
10.3 \pm 1.4\end{array}$ & $\begin{array}{l}9.7 \pm 1.7 \\
9.5 \pm 2.2\end{array}$ & $\begin{aligned} 7.7 & \pm 0.8^{b} \\
10.1 & \pm 1.8\end{aligned}$ & $\begin{array}{l}8.3 \pm 1.4 \\
8.8 \pm 1.7\end{array}$ \\
\hline $\begin{array}{l}* \text { Units in } \mathrm{km}^{*} \mathrm{~h}^{-1} ; * * \text { Units in } \mathrm{w} \\
\text { a } \mathrm{p}<0.05 \text { in relation to the oth } \\
\mathrm{b} p<0.05 \text { in relation to the typ } \\
\mathrm{c} p<0.05 \text { in relation to } \mathrm{EC} \text { for } \\
\mathrm{d} p<0.05 \text { in relation to TR and } \\
\text { e } \mathrm{p}<0.05 \text { in relation to TR and }\end{array}$ & $\begin{array}{l}\text { groups for the san } \\
\text { f exercise within } t \\
\text { same type of exe } \\
\text { for the same typ }\end{array}$ & $\begin{array}{l}\text { ype of exercise. } \\
\text { same group. } \\
\text { e. } \\
\text { exercise. } \\
\text { exercise. }\end{array}$ & & & \\
\hline
\end{tabular}


higher than the one of the EC group for cycling. Likewise, for running, IV $\mathrm{I}_{2 \text { peak }}$ of the TR group was not different from the one of the ER group, and significantly higher than the one of the EC group.

Table 1 shows maximum HR and serum lactate values at the end of the incremental test performed on the cycle ergometer and on the treadmill. Except for EC group, in which no differences were seen, HRmax was significantly lower in cycling than in running. In cycling, HRmax for EC was higher than for ER and TR groups, and similar to UN group. No differences were found in running among the groups. For LACpeak, EC group presented differences only between the types of exercises.

$\dot{\mathrm{V}} \mathrm{O}_{2 \mathrm{AnT}}$ values for cycle ergometer and for treadmill are presented in figure 4 and table $2 . \dot{\mathrm{V}} \mathrm{O}_{2 \mathrm{AnT}}$ was significantly higher in running than in cycling for UN, ER and TR groups.

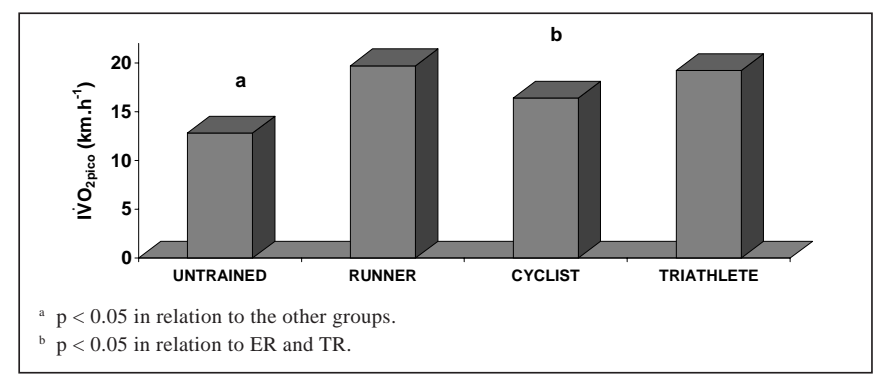

Fig. 2 - Mean intensity values corresponding to $\dot{V} O_{2 p e a k}\left(I \dot{V} O_{2 p e a k}\right)$, from the treadmill for untrained $(U N)$, runners $(E R)$, cyclists $(E C)$ and triathletes (TR) groups

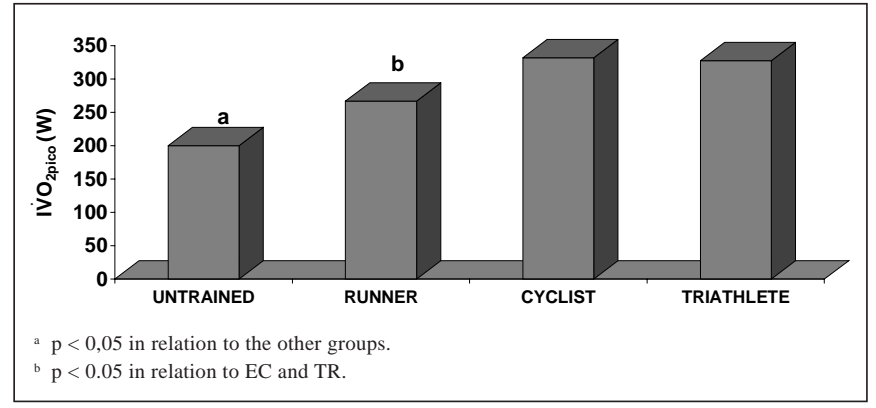

Fig. 3 - Mean intensity values corresponding to $\dot{V} O_{2 p e a k}\left(I \dot{V} O_{2 p e a k}\right)$, from cycle ergometer, for untrained (UN), runners $(E R)$, cyclists $(E C)$ and triathletes $(T R)$ groups

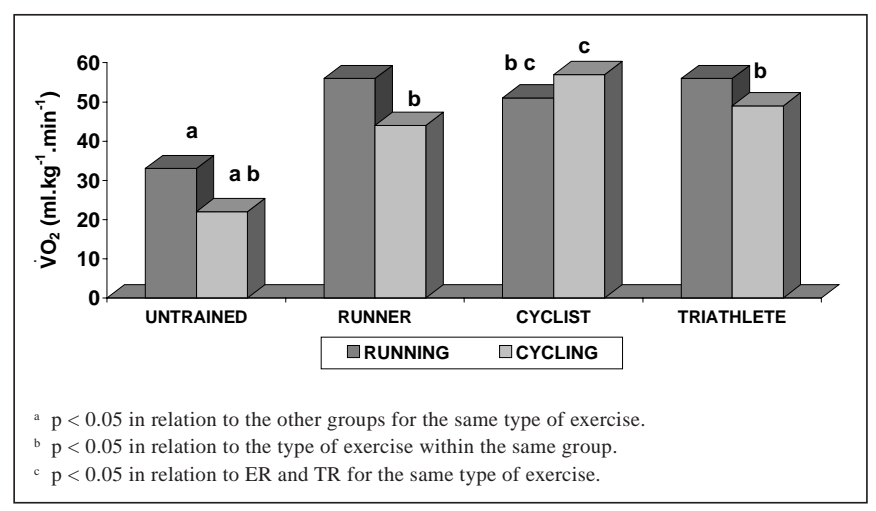

Fig. 4 - Mean oxygen uptake values $\left(\dot{V} \mathrm{O}_{2}\right)$ corresponding to anaerobic threshold, from treadmill and cycle ergometer of untrained (UN), runners $(C R)$, ciclists $(C L)$ e triathletes $(T R)$ groups

\section{TABLE 2}

Mean values \pm SD of oxygen uptake $\left(\dot{V} O_{2 A n T}\right)$, of the proportion of peak oxygen uptake $\left(\% \dot{V} \mathrm{O}_{2 \text { peak }}\right)$, of heart rate (HRAnT), and of the percentage of maximum heart rate (\%HRmax) corresponding to anaerobic threshold (AnT) from cycle ergometer and treadmill for untrained (UN), runners (ER), cyclists (EC) and triathletes (TR) groups

\begin{tabular}{|c|c|c|c|c|c|}
\hline \multirow[t]{2}{*}{ Variables } & \multirow[t]{2}{*}{ Ergometer } & \multicolumn{4}{|c|}{ Group } \\
\hline & & $\begin{array}{c}\text { UN } \\
(n=11)\end{array}$ & $\begin{array}{c}\text { ER } \\
(n=7)\end{array}$ & $\begin{array}{c}E C \\
(n=9)\end{array}$ & $\begin{array}{c}\text { TR } \\
(n=9)\end{array}$ \\
\hline$\dot{\mathrm{V}} \mathrm{O}_{2 \mathrm{AnT}}\left(\mathrm{ml} \cdot \mathrm{kg}^{-1} \cdot \mathrm{min}^{-1}\right)$ & $\begin{array}{l}\text { Treadmill } \\
\text { Cycle }\end{array}$ & $\begin{array}{l}33.2 \pm 4.2^{\mathrm{a}} \\
22.6 \pm 3.7^{\mathrm{ab}}\end{array}$ & $\begin{array}{l}56.8 \pm 6.9 \mathrm{e} \\
44.8 \pm 5.7^{\text {be }}\end{array}$ & $\begin{array}{l}51.2 \pm 5.2^{b c} \\
57.6 \pm 7.1\end{array}$ & $\begin{array}{l}56.5 \pm 5.1^{b} \\
49.0 \pm 4.8^{e}\end{array}$ \\
\hline$\dot{\mathrm{V}} \mathrm{O}_{2 \mathrm{AnT}}\left(\% \mathrm{VO}_{2 \text { peak }}\right)$ & $\begin{array}{l}\text { Treadmill } \\
\text { Cycle }\end{array}$ & $\begin{array}{l}76.6 \pm 6.4^{d} \\
61.6 \pm 5.9^{a b}\end{array}$ & $\begin{array}{l}82.0 \pm 6.6 \\
72.1 \pm 7.2^{\mathrm{bd}}\end{array}$ & $\begin{array}{l}84.6 \pm 6.2 \\
85.1 \pm 4.2\end{array}$ & $\begin{array}{l}87.3 \pm 4.2 \\
81.5 \pm 5.5\end{array}$ \\
\hline HRAnT (bpm) & $\begin{array}{l}\text { Treadmill } \\
\text { Cycle }\end{array}$ & $\begin{array}{l}173.1 \pm 9.1 \\
137.6 \pm 10.7^{\mathrm{ab}}\end{array}$ & $\begin{array}{l}176.2 \pm 6.0 \\
150.8 \pm 9.6^{\text {be }}\end{array}$ & $\begin{array}{l}175.8 \pm 5.7 \\
175.3 \pm 7.8\end{array}$ & $\begin{array}{l}176.2 \pm 8.3 \\
160.7 \pm 8.1^{\text {be }}\end{array}$ \\
\hline \% HRmax & $\begin{array}{l}\text { Treadmill } \\
\text { Cycle }\end{array}$ & $\begin{array}{l}86.4 \pm 2.3 \\
74.1 \pm 5.6^{\mathrm{ab}}\end{array}$ & $\begin{array}{l}89.5 \pm 2.1 \\
83.5 \pm 5.7^{\text {be }}\end{array}$ & $\begin{array}{l}90.2 \pm 3.7 \\
91.5 \pm 2.0\end{array}$ & $\begin{array}{l}91.0 \pm 2.5 \\
87.9 \pm 3.8\end{array}$ \\
\hline $\begin{array}{l}\text { a } p<0.05 \text { in relation to the ot } \\
\text { b } p<0.05 \text { in relation to the ty } \\
\text { c } p<0.05 \text { in relation to ER an } \\
\text { d } p<0.05 \text { in relation to EC an } \\
\text { e } p<0.05 \text { in relation to EC for }\end{array}$ & $\begin{array}{l}\text { roups for the sa } \\
\text { exercise within } \\
\text { the same type o } \\
\text { for the same typ } \\
\text { ame type of ex }\end{array}$ & $\begin{array}{l}\text { ype of exercise. } \\
\text { same group. } \\
\text { ercise. } \\
\text { exercise. }\end{array}$ & & & \\
\hline
\end{tabular}


For EC group, $\dot{\mathrm{VO}}_{2 \mathrm{AnT}}$ was higher in cycling. UN group presented a $\mathrm{VO}_{2 \mathrm{AnT}}$ lower than other groups, for both types of exercise. When ER and EC groups were compared, $\mathrm{VO}_{2 \mathrm{AnT}}$ was higher where athletes had specific training. TR group showed a $\mathrm{VO}_{2 \mathrm{AnT}}$ lower in cycling and higher in running, compared to EC group. For ER group, $\dot{V}_{2 \mathrm{AnT}}$ values of TR group were not different for both types of exercise.

HRAnT, AnT\%HRmax and AnT\% $\dot{V O}_{2 \text { pak }}$, values from cycle ergometer and treadmill are presented in table $2 . \mathrm{AnT}^{\mathrm{V}} \mathrm{V}_{2 \text { peak }}$ values were significantly higher in running than in cycling for ER and UN groups. For TR and EC groups, there were no differences between the exercises. AnT\% $\mathrm{VO}_{2 \text { peak }}$ for cycling in UM group was lower than in ER group, and both groups had lower levels than EC and TR groups. In running, $\mathrm{AnT} \% \mathrm{~V}_{2 \text { peak }}$ was lower for UM group compared to EC and TR groups. Except for EC group, in which no differences were found, HRAnT was significantly lower in cycling than running. HRAnT for UN group in cycling was lower than for the other groups. No differences in HRAnT were found for cycling between ER and TR groups, and both were significantly lower compared to EC group. No differences were found in HRAnT for running, among all groups. AnT\%HRmax values were significantly higher in running than cycling for ER and UN groups. For TR and EC groups, there were no differences between the exercises. AnT\%HRmax for UN group in cycling was lower than the other groups. No AnT\%HRmax differences were found in cycling between ER and TR, and TR and EC groups, but AnT\%HRmax was significantly lower for ER group compared to EC group. There were no AnT\%HRmax differences in running among all groups.

\section{DISCUSSION}

$\dot{\mathrm{V}} \mathrm{O}_{2 \text { pak }}$ and AnT values presented by our subjects are similar to values found in the literature for the profile of those assessed in our investigation ${ }^{8-10}$. Even not interfering in the athletes practice, by associating $\dot{\mathrm{VO}}_{2 \text { paak }}, \mathrm{IVO}_{2 \text { peak }}$ and AnT, we can assume that our subjects underwent adjustments from a long-term aerobic training, regardless of any genetic influence that could raise the levels of such physiologic indices with no training ${ }^{17}$.

According to what is classically demonstrated, TR group tended to make equal their $\dot{\mathrm{V}}_{2 \text { pak }}$ values for both types of exercise $^{18,19}$. UN and ER groups presented higher values for running, while EC group presented a higher value for cycling. This behavior matches the one found in other studies ${ }^{18-21}$, suggesting that $\mathrm{VO}_{2 \text { peak }}$ does not depend only on the muscular mass of the subject, but also on the training specificity. It is interesting to note that $\mathrm{VO}_{2 \text { peak }}$ values presented by ECs and ERs during non-specific training for each group were not different than for the TR group, and significantly higher than the presented by UNs. This suggests a transference of the training effects in relation to aerobic power, both from cycling to running and from running to cycling. This transference, however, seemed to be only partial, as $\dot{\mathrm{V}} \mathrm{2}_{\text {peak }}$ values from ERs were higher in running, compared to ECs, while ECs presented higher values for cycling than ERs. Thus, specific adjustments in $\dot{V}_{2 \text { peak }}$ for improvement of both types of exercise seem to be necessary when one targets the highest $\mathrm{VO}_{\text {2peak }}$ possible and/or when training is performed for highly trained athletes.

There is a huge body of evidence in the literature showing that $\mathrm{V}_{2 \text { paak }}$ in athletes in limited by central factors (maximum heart output $)^{11}$. Our data, however, suggest this behavior may not occur when one assesses athletes performing exercises for which they were not specifically trained. In these conditions, peripheral mechanisms (adjustments in the muscular blood flow and/or oxidative capacity) seem to play a role in limiting $\mathrm{V}_{2 \text { peal }}$. In running, even with similar HRmax values (and likely maximum heart output) to cycling, $\dot{\mathrm{V}} \mathrm{O}_{2 \text { peak }}$ values for EC group were higher in cycling. In cycling, peripheral factors seem to be even more present, as both groups, ER and TR, presented lower HRmax (and likely a maximum heart output) for running. It is likely that very specific adjustments are necessary for the muscle groups used in cycling (as discussed below), so that no peripheral limitation may prevent HRmax to be reached during an incremental test.

$\mathrm{IVO}_{2 \text { peak }}$ is the index that reflects the best the association between maximum aerobic power $\left(\mathrm{V}^{2} \mathrm{Ppaak}\right)$ and economy of movement ${ }^{22}$. As expected, $\mathrm{IVO}_{2 \text { peak }}$ was higher where the athlete had specific training for the modality, and much lower in both tests for the UNs, with values within the range shown in the literature for this type of sample ${ }^{15}$ (figures 2 and 3 ). It is important to mention that higher $I \mathrm{IVO}_{\text {2peak }}$ values were not due to higher $\mathrm{VO}_{2 \text { peak }}$ only, but also because of a higher economy of movement in the modality in which the subject had specific training. This can be better seen by observing $I \mathrm{VO}_{2 \text { peak }}$ values for the modality not particular to that subject. For ER (cycling) and EC (running) groups, $\dot{\mathrm{V}} \mathrm{O}_{2 \text { peak }}$ values were similar to TR group, whereas $\mathrm{IV}_{2 \text { peak }}$ values were significantly lower in ER and EC groups. These data show that economy of movement has an instrumental role in determining $I \mathrm{VVO}_{2 \text { peak }}$, and that transference from one type of exercise to another probably did not occur, or was too small. Economy of movement depends on specific peripheral adjustments (enzymatic, neuromuscular and motor technique), that makes difficult transference of training effects. Our data confirm the importance of determining $\mathrm{IV}_{2 \text { peak }}$, and not only $\dot{\mathrm{V}} \mathrm{O}_{2 \text { peak }}$, which reinforces findings of other studies that concluded $\mathrm{IVO}_{2 \text { peak }}$ to be more valid to ex- 
plain individual differences in aerobic performance than $\dot{\mathrm{V}} \mathrm{O}_{\text {2pak }}$ or economy of movement alone ${ }^{12}$.

For submaximal variables, again AnT highest values were for subjects with specific training in the modality (figure 4). The same goes for $\mathrm{VO}_{2 \text { peak }}$, suggesting that high AnT adjustment levels in response only to specific training. It is to be mentioned, however, that AnT presented by UNs in both exercises are much lower that values found in ECs for running and ERs for cycling, suggesting a transference, even if partial, of training effects. However, different from what was seen with $\mathrm{VO}_{2 \text { peak }}$, these values (for ECs in running and ERs in cycling) were lower than those presented by TRs, showing that transference of training effects, even if partial, are more specific in lactate response than in $\dot{\mathrm{VO}}_{2 \text { peak }}$.

In our study model, AnT expressed in absolute values $\left(\mathrm{ml} \cdot \mathrm{kg}^{-1} \cdot \mathrm{min}^{-1}\right)$ should be analyzed with discretion, as differences among groups for this index may be determined, in great measure, by the different $\mathrm{V}_{2 \text { peak }}$ values. However, when AnT is expressed as a $\dot{\mathrm{V}}_{2 \text { peak }}$ percentage $\left(\mathrm{AnT} \% \dot{\mathrm{V}}_{2 \text { peak }}\right)$, i.e., relative values, its behavior is not different from what was previously discussed, except for the similarity in UN and ER groups in running. In this scenario, it is to be stressed that the type of exercise seems to interfere in $\mathrm{AnT}_{\mathrm{V}} \mathrm{VO}_{2 \text { peak }}$, particularly when one observes that UN group presented a value for running similar to the ER group, significantly higher than its value for cycling.

The lower AnT\% $\mathrm{VO}_{2 \text { paak }}$ (UN) and HRmax (UN, ER and TR) values for cycling compared to running may be due to biomechanical differences among the different modalities. Even using similar muscle groups, the delta efficiency $(\Delta$ intensity/ $\left.\Delta \dot{\mathrm{V}}_{2} \times 100\right)$ for cycling $(25 \%)$ is much lower than for running $(45 \%)^{23}$. Its contractions of isomeric characteristics ${ }^{24}$ somehow may influence, through the decrease of muscular pumping action, venous return and muscular blood flow during exercise. During high-intensity activities, particularly in subjects with no cycling experience, as fatigue develops, one could observe an increase in the work of trunk and upper limb muscles, with no contribution for the generation of external work. This may cause blood flow to be redirected to the upper part of the body, and a possible "competition" for heart output. In addition, high intramuscular pressures developed over the cycling cycle may lead to a partial occlusion of the femoral artery ${ }^{25}$, which may reduce oxygen supply and promote higher recruitment of type-II fibers. It is thus possible to speculate that, during cycling, more specific adjustments may be necessary in an attempt to decrease these biomechanical limitations.

For running, excentric muscular action may be of important consequences for energetic expenditure. First, the metabolic expenditure from the excentric concentration is substantially lower than the concentric contraction ${ }^{26}$. Sec- ond, the enlarging-shortening cycle in running allows for the storage of elastic energy during the excentric stage, which is released later, at the concentric stage, increasing power generation for a given neural impulse. Such biomechanical "benefit" of running seems to justify, in part, the higher transference of $\mathrm{AnT}_{\%} \mathrm{~V}_{\text {2peak }}$ towards running, and also $\mathrm{AnT} \% \mathrm{VO}_{2 \text { peak }}$ and HRmax behavior in groups that do not train cycling.

Based on data from this study, one may conclude that, regardless of the index $\left(\dot{\mathrm{VO}}_{2 \text { peak }}, \mathrm{IV}_{2} \mathrm{O}_{2 \text { eak }}\right.$ or $\left.\mathrm{AnT}\right)$ or the type of exercise (running or cycling), transferences of training effects seem to be just partial, and there is the need to meet the movement specificity principle, when one intends to get a high degree of physiologic adjustment. As for indices, training specificity seems to be less present, therefore promoting higher level of transference, when adjustments depend more on central factors, such as $\dot{V}_{2 \text { peak }}$. For $I \dot{V} O_{2 \text { peak }}$ (when $\dot{\mathrm{VO}}_{2 \text { peak }}$ levels are high) and AnT, which are more dependent on peripheral adjustments, the degree of transference may be lower.

All the authors declared there is not any potential conflict of interests regarding this article.

\section{REFERENCES}

1. Magel JR, Foglia GF, McArdle WD, Gutin B, Pechar GS, Katch FI. Specificity of swim training on maximum oxygen uptake. J Appl Physiol 1975; 38:151-5.

2. Bhambhani YN, Eriksson P, Gomes PS. Transfer effects of endurance training with the arms and legs. Med Sci Sports Exerc 1991;23:1035-41.

3. Millet GP, Candau RB, Barbier B, Busso T, Rouillon JD, Chatard JC. Modelling the transfers of training effects on performance in elite triathletes. Int J Sports Med 2002;23:55-63.

4. Boutcher SH, Seip RL, Hetzler RK, Pierce EF, Snead D, Weltman A. The effects of specificity of training on rating of perceived exertion at the lactate threshold. Eur J Appl Physiol 1989;59:365-9.

5. Loy SF, Shapiro BI, Hoffmann JJ. Effect of running versus cycle training on cycle ergometer, treadmill, and running performance. Sports Med Training Rehabilitation 1993;4:1-9.

6. Pechar GS, McArdle WD, Katch FI, Magel JR, DeLuca J. Specificity of cardiorespiratory adaptation to bicycle and treadmill training. J Appl Physiol 1974;36:753-6.

7. Shephard RJ, Allen C, Benade AJ, Davies CT, di Prampero PE, Hedman $\mathrm{R}$. The maximum oxygen intake. An international reference standard of cardiorespiratory fitness. Bull World Health Organ 1968;38:757-64.

8. Kohrt WM, O'Connor JS, Skinner JS. Longitudinal assessment of responses by triathletes to swimming, cycling, and running. Med Sci Sports Exerc 1989;21:569-75.

9. Brandon LJ. Physiological factors associated with middle distance running performance. Sports Med 1995;19:268-77.

10. Caputo F, De Lucas RD, Mancini E, Denadai BS. Comparação de diferentes índices obtidos em testes de campo para predição da performance aeróbia de curta duração no ciclismo. Rev Bras Ciênc Mov 2001;9:13-7. 
11. Saltin B, Strange S. Maximal oxygen uptake: "old" and "new" arguments for a cardiovascular limitation. Med Sci Sports Exerc 1992;24: 30-7.

12. Daniels JA, Daniels N. Running economy of elite male and elite female runners. Med Sci Sports Exerc 1992;24:483-9.

13. Billat VL, Mille-Hamard L, Demarle A, Koralsztein JP. Effect of training in humans on off- and on-transient oxygen uptake kinetics after severe exhausting intensity runs. Eur J Appl Physiol 2002;87:496-505.

14. Denadai BS. Índices fisiológicos de avaliação aeróbia: Conceitos e aplicações. Ribeirão Preto, SP: BSD, 1999.

15. Billat VL, Faina M, Sardella F, Marini C, Fanton F, Lupo S, et al. A comparison of time to exhaustion at $\mathrm{VO}_{2}$ max in elite cyclists, kayak paddlers, swimmers and runners. Ergonomics 1996;39:267-77.

16. Heck H, Mader A, Hess G, Mucke S, Muller R, Hollmann W. Justification of the $4 \mathrm{mmol} / \mathrm{l}$ lactate threshold. Int J Sports Med 1985;6:117-30.

17. Jeukendrup AE, Craig NP, Hawley JA. The bioenergetics of world class cycling. J Sci Med Sport 2000;3:414-33.

18. Boussana A, Matecki S, Galy O, Hue O, Ramonatxo M, Le Gallais D. The effect of exercise modality on respiratory muscle performance in triathletes. Med Sci Sports Exerc 2001;33:2036-43.

19. Denadai BS, Piçarro IC, Russo AK. Consumo máximo de oxigênio e limiar anaeróbio determinados em testes de esforço máximo, na esteira rolante, bicicleta ergométrica e ergômetro de braço em triatletas brasileiros. Rev Paul Ed Física 1994;8:49-57.

20. Bouckaert J, Vrijens J, Pannier JL. Effect of specific test procedures on plasma lactate concentration and peak oxygen uptake in endurance athletes. J Sports Med Phys Fitness 1990;30:13-8.

21. Fernhall B, Kohrt W. The effect of training specificity on maximal and submaximal physiological responses to treadmill and cycle ergometry. J Sports Med Phys Fitness 1990;30:268-75.

22. Machado FA, Guglielmo LGA, Denadai BS. Velocidade de corrida associada ao consumo máximo de oxigênio em meninos de 10 a 15 anos. Rev Bras Med Esporte 2002;8:1-6.

23. Daniels J, Daniels N. Running economy of elite male and elite female runners. Med Sci Sports Exerc 1992;24:483-9.
24. Bijker KE, Groot G, Hollander AP. Delta efficiencies of running and cycling. Med Sci Sports Exerc 2001;33:1546-51.

25. Patterson RP, Moreno MI. Bicycle pedaling forces as a function of pedaling rate and power output. Med Sci Sports Exerc 1990;22:512-6.

26. Edwards RH, Hill DK, Mcdonnell M. Myothermal and intramuscular pressure measurements during isometric contractions of the human quadriceps muscle. J Physiol 1972;224:58-9.

27. Van Ingen Schenau GJ, Bobbert MF, De Haan A. Does elastic energy enhance work and efficiency in the stretch-shortening cycle? J Appl Biomech 1997;13:389-415.

19. Denadai BS, Piçarro IC, Russo AK. Consumo máximo de oxigênio e limiar anaeróbio determinados em testes de esforço máximo, na esteira rolante, bicicleta ergométrica e ergômetro de braço em triatletas brasileiros. Rev Paul Ed Física 1994;8:49-57.

20. Bouckaert J, Vrijens J, Pannier JL. Effect of specific test procedures on plasma lactate concentration and peak oxygen uptake in endurance athletes. J Sports Med Phys Fitness 1990;30:13-8.

21. Fernhall B, Kohrt W. The effect of training specificity on maximal and submaximal physiological responses to treadmill and cycle ergometry. J Sports Med Phys Fitness 1990;30:268-75.

22. Machado FA, Guglielmo LGA, Denadai BS. Velocidade de corrida associada ao consumo máximo de oxigênio em meninos de 10 a 15 anos. Rev Bras Med Esporte 2002;8:1-6.

23. Daniels J, Daniels N. Running economy of elite male and elite female runners. Med Sci Sports Exerc 1992;24:483-9.

24. Bijker KE, Groot G, Hollander AP. Delta efficiencies of running and cycling. Med Sci Sports Exerc 2001;33:1546-51.

25. Patterson RP, Moreno MI. Bicycle pedaling forces as a function of pedaling rate and power output. Med Sci Sports Exerc 1990;22:512-6.

26. Edwards RH, Hill DK, Mcdonnell M. Myothermal and intramuscular pressure measurements during isometric contractions of the human quadriceps muscle. J Physiol 1972;224:58-9.

27. Van Ingen Schenau GJ, Bobbert MF, De Haan A. Does elastic energy enhance work and efficiency in the stretch-shortening cycle? J Appl Biomech 1997;13:389-415. 